\title{
HISTOPATHOLOGY ANALYSIS OF Sciades herzbergii (PISCES, ARIIDAE) AND Bagre bagre (PISCES, ARIIDAE) GILLS TO ASSESS ENVIRONMENTAL POLLUTION
}

\author{
VIANA, H. C. ${ }^{*}$ - SILVA, S. K. L. ${ }^{2}-$ JoRGE, M. B. ${ }^{3}-$ SILVA, M. H. L. ${ }^{4}-$ SANTOS, D. M. S. ${ }^{1,5}$ \\ CARVALHO NETA, R. N. F. ${ }^{1,5^{*}}$ \\ ${ }^{1}$ Postgraduate Program in Aquatic Resources and Fisheries, State University of Maranhão \\ (UEMA), University City Paulo VI s/n, Cidade Operária, São Luís, Maranhão, Brazil \\ ${ }^{2}$ Postgraduate Program in Biodiversity and Conservation by Federal University of Maranhão \\ (UFMA), Avenue of Portugueses, 1966, Vila Bacanga, São Luis, Maranhão, Brazil \\ ${ }^{3}$ Postgraduate Program in Oceanography, Federal University of Maranhão (UFMA), São Luís, \\ Maranhão, Brazil \\ ${ }^{4}$ Department of Oceanography and Limnology, Postgraduate Program in Development and \\ Environment, Federal University of Maranhão (UFMA), São Luís, Maranhão, Brazil \\ ${ }^{5}$ Department of Biology, State University of Maranhão (UEMA), São Luis, Maranhão, Brazil \\ *Corresponding author \\ e-mail: hellonviana@gmail.com \\ (Received 15 $5^{\text {th }}$ Jan 2021; accepted $14^{\text {th }}$ May 2021)
}

\begin{abstract}
The objective of this research was to evaluate changes found in the gills and livers of Sciades herzbergii and Bagre bagre to verify damage associated with pollution in mangrove regions on the north coast of Brazil. Biological samples were collected in Curupu Bay (Brazil) in an environmental gradient, involving a control area (A1), a site with fish farming effluents (A2), a region with domestic sewage from an urban city (A3) and a more away site from the coast (A4). The greatest percentage of gill injuries were recorded for $S$. herzbergii, which live in area A2 in relation to the rest of the studied areas. Histopathological analysis showed an elevated number of hepatic alterations such as inflammatory responses, melanomacrophage centers, hyperplasia and cytoplasmic vacuolization (lipid cells) in $S$. herzbergii from area A2. It was also possible to identify a significant difference in the liver index (Iorg.) of fish, which live in area A2 compared to that of fish from to the other areas. Hepatosomatic index values (HSI) and condition factor $(\mathrm{K})$ were similar in areas A1, A2 and A3, however differed in area A4. Fish from areas A3 and A2 had the largest number of liver abnormalities (fat nodes).
\end{abstract}

Keywords: biomonitoring, catfish, bioindicator, contamination, condition factor

\section{Introduction}

Anthropogenic changes such as rapid population growth and urbanization of large areas have led to a decline in the quality of aquatic ecosystems (Pérez et al., 2018). In addition, water quality directly relates to the sanitary conditions of humans and animals that inhabit these environments (Ghisi et al., 2016). Uncontrolled domestic and industrial effluent discharges, agrochemical dumps, heavy metals, organic compounds among other xenobiotics (Van der Oost et al., 2003) directly affect fish. In this sense, fish are sentinel organisms that can be used as bioindicators of environmental stress, both of abiotic and biotic changes caused by pollutants (Carvalho Neta et al., 2014; Pinheiro-Sousa et al., 2013). The first responses of organisms to stress are changes at the cellular and tissue levels (Facey et al., 2005). 
Fish gills have a large surface in direct contact with water, gill changes have been widely used as environmental contamination indicators (Olivares-Rubio and VegaLópez, 2016; Zhang et al., 2014). Experimental studies have assessed gill damage induced by xenobiotics, such as heavy metals and pesticides (Garcia-Santos et al., 2007; Carvalho-Neta and Abreu-Silva, 2013; Olurin et al., 2016) and gill structure after a period of exposure to contaminants and being relocated to good quality environments (Sales et al., 2017; Choi et al., 2018).

Studies on species from the South American continent, USA, Europe, Africa and Asia have shown that liver histopathology, through highlighting alterations found in the liver is an advantageous exposure biomarker of contaminants ( $\mathrm{Au}, 2004$; Triebskorn et al., 2008; Van Dyk et al., 2012; Zhang et al., 2014; Pérez et al., 2018; Sardi et al., 2016). Some of these studies were incorporated into biomonitoring programs and programs of this nature require a level of histopathological data and biomonitoring fish species from the region in question (Carvalho-Neta and Abreu-Silva, 2010).

The northern region of Maranhão is well developed for its proximity to port complexes and accelerated urban and industrial development (Carvalho-Neta et al., 2012). As a result, many water bodies have suffered negative impacts related to releases of industrial effluents, untreated sewage, among others (Cantanhêde et al., 2014).

Among pollutant mixtures, fishery effluents stand out the most, containing ammonia and nitrite, which are toxic compounds for aquatic organisms. These pollutants are present in the natural environment through aquatic organism excretion; however, they can increase their concentrations through the processes of unconsumed food degradation and incomplete nitrification (dos Santos Silva et al., 2018). Aquaculture has been responsible for continued growth in fish supplying for human consumption $(47 \%$ of 171 million tons produced in 2016), because since the 1980s, fish production has been relatively static (FAO, 2018). Aquaculture in Brazil produced more than 586 thousand tons of fish (70.9\% referring to fish farming followed by $19.3 \%$ to shrimp farming) (IBGE, 2016). Maranhão currently occupies the seventh position in fish production, climbing two positions in comparisons to bulletins published in previous years (IBGE, 2016).

Exposure regimes for pollutants experienced by fish are difficult to determine. Often, there is fluctuation of chemicals in the river water due to varying rates of biodegradation as well as physical-chemical conditions and water flow rates. These factors may alter the levels of effluent dilution and fish movements between habitats (Vrana et al., 2005). However, some histological changes, such as hyperplasia, cell hypertrophy and vascular damage depending on the number of lesions assessed may be indicators of acute environmental contamination by pollutants (Carvalho Neta et al., 2014). The taxon Sciades herzbergii is a typical benthic fish and maintains a close relationship with the environment; it is common to coastal areas and has been used as a model for the effect of contaminants in estuarine systems (Carvalho-Neta et al., 2012). Bagre bagre is a migratory species which resides in estuarine environments in Maranhão (Pinheiro-Sousa et al., 2013). These catfish species are widely distributed and are used for research because of their sedentary habit and economic importance for river front communities and small-scale fisheries (Carvalho Neta et al., 2014) which are located throughout the Santo Antônio River basin and Curupu Bay (Brazil). This region contains a large mangrove forest and many fishing communities still live in the region. However, the recent urban growth has caused impacts not yet measured and no studies have been done for catfish species in an environmental gradient (with different levels of 
impact) in the mangroves in the region. Thus, the objective of this research was to evaluate changes found in the gills and livers of Sciades herzbergii and Bagre bagre to verify damage associated with pollution in mangrove regions on the north coast of Brazil (Curupu Bay).

\section{Materials and methods}

The four selected collection sites are located between the mouth of the Santo Antônio River and Curupu Bay, in the eastern region of São Luís Island, Maranhão State, Brazil (Fig. 1). It is characterized as a rural region, marked by extensive mangrove areas. However, there is an accelerated urbanization process. A region at the mouth of the river, and therefore further away from the banks of the river, was selected as reference area for S. herzbergii (A1 - $2^{\circ} 27^{\prime} 47.58^{\prime \prime}$ S 44 $2^{\prime} 45.42^{\prime \prime}$ ). A closer and more accessible location to the channel, where fishery effluents are theoretically released, was

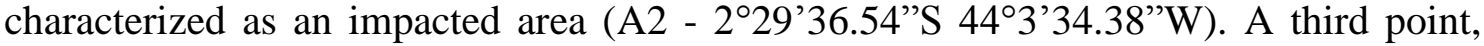
within an urban center, which constantly suffers from domestic effluent releases was selected as a contaminated area (A3 - 2 $\left.33^{\circ} 18.36^{\prime \prime} S 44^{\circ} 3^{\prime} 10.02^{\prime \prime} \mathrm{W}\right)$. In addition, a fourth, further away from the coast, was selected as reference area for the B. bagre A4 (2²8'56.64"S 441'44.40"W). Shipments left the Port of Pau Deitado, municipality of Paço do Lumiar and they took a motorized vessel called "biana".
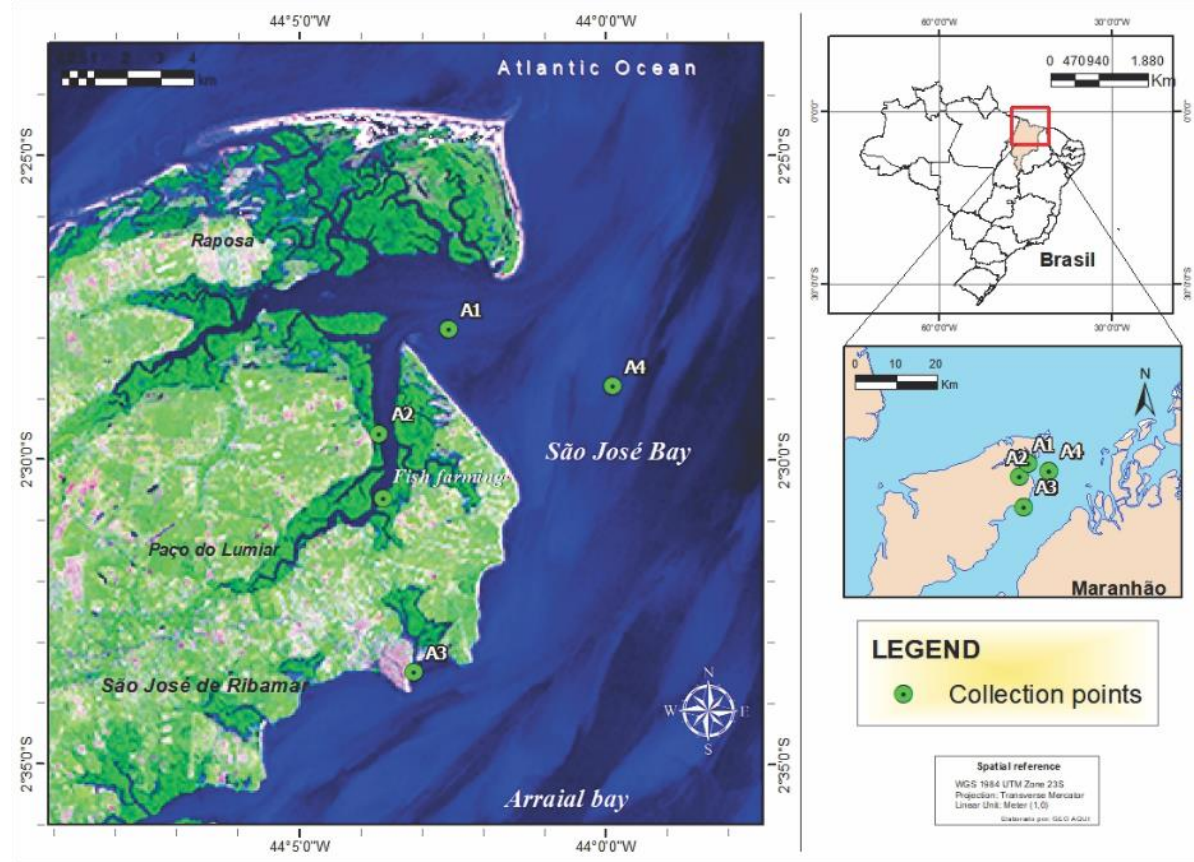

Figure 1. Geographic location of S. herzbergii and B. bagre catches at the Santo Antonio River basin and Curupu Bay estuary complex, Maranhão

The capture of fish was authorized by the Ethics Committee of Maranhão State University (number 064/2017-2018 CRMV-MA) and met the guidelines of the Brazilian College for Animal Experimentation (RN39 CONCEA, 2018).

During all sampling, 115 catfish were collected, with $\mathrm{A} 1=22 ; \mathrm{A} 2=20 ; \mathrm{A} 3=31$; A4 $=42$. The collection of $S$. herzbergii was carried out with the use of cages, known as 
"manzuá". Sardines were used as bait, arranged on cords up to $3 \mathrm{~kg}$ and tied inside of the cages. The cages were installed during the low tide, in low depths and left overnight, when the harvesting occurred. The collection of B. bagre was carried out using floating gill nets with a mesh of 15 to $40 \mathrm{~mm}$ between adjacent nots, 4 to 5 meters in height and 200 meters in length for catches. Samplings occurred during the quadrature tide with standard fishing effort of $6 \mathrm{~h}$, corresponding to the entire ebb. The fish were acclimatized in thermal iceboxes to the Laboratory of Biomarkers in Aquatic Organisms at the State University of Maranhão (LABOAq/UEMA). Measurement of total length $(\mathrm{cm})$ and total weight $(\mathrm{g})$ were carried out to calculate condition factor according to specific methodology (Vazzoler, 1996). Evisceration was performed for macroscopic identification of maturational stages, where: I - Immature, II - In development, III Able to spawn, IV - Regression and V - Regeneration (Brown-Peterson et al., 2011). The liver of each fish was weighed to calculate the hepatosomatic index (HSI) (liver mass/body mass x 100). The gonadosomatic index (GSI) was also evaluated (gonad mass/body mass $x$ 100), it is the value that expresses body weight allocated in the gonads.

Abiotic data measured with assistance from the AK88 multi-parameter (INSTRUBRAS), temperature $\left({ }^{\circ} \mathrm{C}\right)$ probes, salinity, $\mathrm{pH}$ and dissolved oxygen (DO) helped in the water quality analysis.

The same LABOaq team collected fish and tissue samples from each sampling point where the same methodological process was applied. A basic histology procedure was applied, fish were dissected and liver and gill samples were set in $10 \%$ formaldehyde, gills were decalcified with nitric acid and later the organs were dehydrated in increasing alcohol concentrations, they were diaphanized in xylol and went through paraffin inclusion. Sections of liver and gills $(5 \mu \mathrm{m})$ were stained with hematoxylin-eosin (H\&E) (Merck) for hepatic and branchial structure description, respectively.

The optic microscope (Axioskop-Zeiss) assisted in the quantitative assessment of histological changes. The liver and gill slides were inspected with $4 \mathrm{X}, 10 \mathrm{X}$ and $40 \mathrm{X}$ lenses, depending on the lesion. To determine the degree of hepatic and branchial lesion severity, the water pollution assessment protocol proposed by Bernet et al. (1999) was used. In short, histological changes were assessed according to identification of changes in five reaction patterns (rp). Where: rp1 - circulatory disorders (hemorrhage, hyperemia, aneurysm and intercellular edema); rp2 - regressive changes (structural changes, atrophy, deposits, necrosis, changes in plasma and nuclear alterations); rp3 progressive changes (hyperplasia and hypertrophy); rp4 - inflammation (exsudase, reticuloendothelial system activation and infiltration) and rp5 - tumors (benign and malignant).

When the lesion was identified, the importance factor (w) was evaluated at three levels: 1 - minimal pathological or reversible importance; 2 - moderate pathological or reversible importance in most cases and 3 - marked pathological or irreversible importance. We also recorded the extent of the histological alteration, which classified degree and extent of the lesion (a): 0 (no changes), 2 (mild occurrence), 4 (moderate occurrence), and 6 (severe occurrence), with intermediate values also being considered.

Since lesions of each organ were studied separately, the calculation of two indices were applied, the organ index $\left(\mathrm{I}_{\text {org. }}\right)(E q .1)$ and organ reaction index $\left(\mathrm{I}_{\text {org rp }}\right)(E q .2)$, as proposed by Bernet et al. (1999):

$$
\mathrm{I}_{\text {org. }}=\Sigma \mathrm{rp} \Sigma \text { alt }(\text { a.w })
$$


where: org $=$ organ $($ constant); $\mathrm{rp}=$ reaction standard; alt $=$ alteration found in the organ; $\mathrm{a}=$ alteration extension degree; $\mathrm{w}=$ importance factor.

The index represents a degree of organ damage. It is the result of the sum of multiplying importance factors with the values from all changes found in the examined organ. A high index indicates a high degree of damage.

$$
\mathrm{I}_{\text {orgrp }}=\Sigma \text { alt (a.w) }
$$

where: org and $\mathrm{rp}=$ constant.

Lesions in an organ is expressed by the reaction index. It is calculated by the sum of multiplying the importance factor with the value of the corresponding standard reaction alterations. The sum of the organ reaction's five indices (Irp1; Irp2; Irp3; Irp4 e Irp5) is equivalent to the organ index ( $\mathrm{I}_{\text {org. }}$ ).

Descriptive statistics are presented in the form of averages, standard deviations, medians and percentage prevalence. Histological results, hepatosomatic and condition factor variation, and quantitative were compared between sites using the ANOVA variance test and Tukey test. Statistical analyses were performed using the software PAlaeontological STatistics (PAST), version 1.0.0.0 (Hammer et al., 2001) and statistical significance was accepted for $\mathrm{p} \leq 0.05$. Melanomacrophage Centers (MMC) quantity results were compared between sites using the Kruskal-Wallis test. For variables with a significant test result, comparisons between pairs between different sites were made using the Mann-Whitney non-parametric U test, controlling the Type I error between the tests by Bonferroni adjustment. Data was checked for normality using the Kolmogorov-Smirnov or Shapiro-Wilk tests.

\section{Results}

In the first collection (September/2017 - dry season), four fish were caught at point A1, 10 fish at point A2 and 11 fish at point A4. In the second collection (December/2017 - dry season), six fish were collected at point A1, 3 fish at point A2, 12 fish at point A3 and 11 fish at point A4. In the third collection (March/2018 - rainy season), 6 fish from point A1, 2 fish from point A2, 11 fish from point A3 and 9 fish from point A4 were captured. In the fourth and final collection (May/2018 - rainy season), six fish were caught at point A1, 5 fish at A2 points, 8 fish at point A3 and 11 fish at point A4. In total, 73 individuals of $S$. herzbergii (24 males and 49 females) and 42 B. bagre (27 males and 15 females) were collected (Table 1).

At point A1, it was divided among 12 juveniles and 10 adults; at point A2, 16 juveniles and 4 adults; at point A3, specimens were divided into 7 juveniles and 24 adults and finally, at point A4, 24 juveniles and 18 adults were identified. Biometric data (Lt - total length, Ls - standard length, Wt - total weight, Wg - weight of gonads and GSI - gonadosomatic index) of fish collected in Curupu Bay are shown. Females from the A1 area showed the highest length and weight averages, whereas males from the A3 area had the smallest average size, and males and females from the A4 area showed lower average weight. The fish in the A2 area were mostly juveniles and presented lower average GSI. In relation to the physical parameters of the water measured, $\mathrm{pH}$, temperature and dissolved oxygen were uniform in all analyzed areas and periods. Salinity showed greater variation between drought and rainy periods. All 
parameters sampled were in compliance with Brazilian legislation (Resolução No 357, 2005) (Table 2).

Table 1. Biometric data and gonadosomatic index of S. herzbergii and B. bagre captured at Curupu bay

\begin{tabular}{c|c|c|c|c|c|c}
\hline $\begin{array}{c}\text { Sampling } \\
\text { point }\end{array}$ & Gender & Lt $(\mathbf{c m})$ & Ls $(\mathbf{c m})$ & Wt $(\mathbf{g})$ & Wg $(\mathbf{g})$ & GSI \\
\hline \multirow{2}{*}{ (A1) } & Females & $34.50 \pm 4.60$ & $28.57 \pm 3.88$ & $399.77 \pm 153.75$ & $6.3415 \pm 5.8604$ & $1.3151 \pm 1.0912$ \\
& Males & $28.57 \pm 4.00$ & $22.12 \pm 4.81$ & $237.89 \pm 115.85$ & $0.2433 \pm 0.3364$ & $0.0787 \pm 0.0688$ \\
\hline \multirow{2}{*}{ (A2) } & Females & $30.72 \pm 4.31$ & $25.47 \pm 3.94$ & $286.85 \pm 113.66$ & $3.0635 \pm 3.9105$ & $0.9941 \pm 1.1658$ \\
& Males & $20.27 \pm 9.67$ & $16.99 \pm 8.27$ & $281.71 \pm 65.52$ & $0.2872 \pm 0.2401$ & $0.1112 \pm 0.1085$ \\
\hline \multirow{2}{*}{ (A3) } & Females & $30.25 \pm 3.68$ & $25.03 \pm 2.88$ & $269.22 \pm 100.55$ & $5.3420 \pm 5.8499$ & $1.6152 \pm 1.5846$ \\
& Males & $26.25 \pm 3.03$ & $21.69 \pm 2.69$ & $177.25 \pm 60.12$ & $0.2107 \pm 0.1031$ & $0.1286 \pm 0.0710$ \\
\hline \multirow{2}{*}{ (A4) } & Females & $29.02 \pm 2.95$ & $23.03 \pm 2.44$ & $165.13 \pm 55.56$ & $2.9654 \pm 10.0217$ & $1.2378 \pm 4.0645$ \\
& Males & $28.02 \pm 3.42$ & $22.12 \pm 2.86$ & $144.96 \pm 46.30$ & $0.1912 \pm 0.2037$ & $0.1415 \pm 0.1488$ \\
\hline
\end{tabular}

Values given as mean $(\overline{\mathrm{x}})$ and standard deviation $( \pm \mathrm{SD})$. Lt: total length; Ls: standard length; $\mathrm{Wg}$ : weight of gonad; GSI: gonadosomatic index

Table 2. Physical parameters of water (mean) recorded in dry and rainy periods at the fish collection sites

\begin{tabular}{|c|c|c|c|c|c|c|c|}
\hline \multirow[b]{2}{*}{ Parameters } & \multicolumn{2}{|c|}{ (A1) } & \multicolumn{2}{|c|}{ (A2) } & \multicolumn{2}{|c|}{ (A3) } & \multirow{2}{*}{$\begin{array}{l}\text { Recommended } \\
\text { values }^{\mathrm{a}}\end{array}$} \\
\hline & $\begin{array}{c}\text { Dry } \\
\text { season }\end{array}$ & $\begin{array}{l}\text { Rainy } \\
\text { season }\end{array}$ & $\begin{array}{c}\text { Dry } \\
\text { season }\end{array}$ & $\begin{array}{l}\text { Rainy } \\
\text { season }\end{array}$ & $\begin{array}{c}\text { Dry } \\
\text { season }\end{array}$ & $\begin{array}{l}\text { Rainy } \\
\text { season }\end{array}$ & \\
\hline $\mathrm{pH}$ & 7.57 & 7.40 & 7.42 & 7.41 & 7.46 & 7.70 & from 6.5 to 8.5 \\
\hline Temp. $\left({ }^{\circ} \mathrm{C}\right)$ & 30.20 & 29.65 & 33.30 & 30.40 & 31.60 & 31.20 & $<40^{\circ} \mathrm{C}$ \\
\hline DO (mg/L) & 8.76 & 11.19 & 9.14 & 9.91 & 8.69 & 11.16 & $>5 \mathrm{mg} / \mathrm{L}$ \\
\hline Salinity & 37.50 & 27.05 & 37.45 & 26.65 & 38.70 & 26.60 & \\
\hline
\end{tabular}

Values given as mean $(\overline{\mathbf{x}})$. pH: hydrogenic potential; Temp.: temperature; DO: dissolved oxygen Reference area (A1); impacted area (A2); contaminated area (A3)

${ }^{\text {a}}$ Recommended values based on resolution nos. 357 and 430 of Brazil's National Environmental Council, CONAMA 2005

The HSI and $\mathrm{K}$ variation from four different research areas were investigated. The highest HSI averages were found in area A1 $(1.77 \pm 0.44)$ and A3 $(1.98 \pm 0.42)$ and the lowest averages were found in areas A2 $(1.73 \pm 0.37)$ and A4 (1.07 \pm 0.38$)$ (Fig. 2A). The greatest HSI variations occurred at points $\mathrm{A} 3$ and $\mathrm{A} 4$, as demonstrated in the boxplot quartiles compared with the smallest variations at areas A1 and A2. A statistical difference was noted in relation to point A4 and the other collection sites ( $<$ < 0.05).

The average $\mathrm{K}$ of all fish sampled from areas A1, A2, A3 and A4 was $0.98 \pm 0.08$, $1.03 \pm 0.10,1.00 \pm 0.08$ and $1.52 \pm 0.14$, respectively. The highest variation in $\mathrm{K}$ value occurred with individuals from point A4. The variation of the other groups was similar, with the A1 group indicating a lower $\mathrm{K}$ than expected $(\mathrm{K}=1)$. The condition factor of S. herzbergii ranged from 1.0387 to 0.9672 for area A1. K ranged from 1.0432 to 0.9700 in area A2 and decreased from 1.0433 to 0.9800 in area A3. The ANOVA did not show significant values of $\mathrm{K}$ in fish from points $\mathrm{A} 1, \mathrm{~A} 2$ and $\mathrm{A} 3$, but there was a 
significant difference in relation to the A4 point ( $\mathrm{p}<0.05$ ). The condition factor of each fish was examined and the monthly average indicated that, in at least two different periods of the year, fish were in good condition (Fig. 2B).

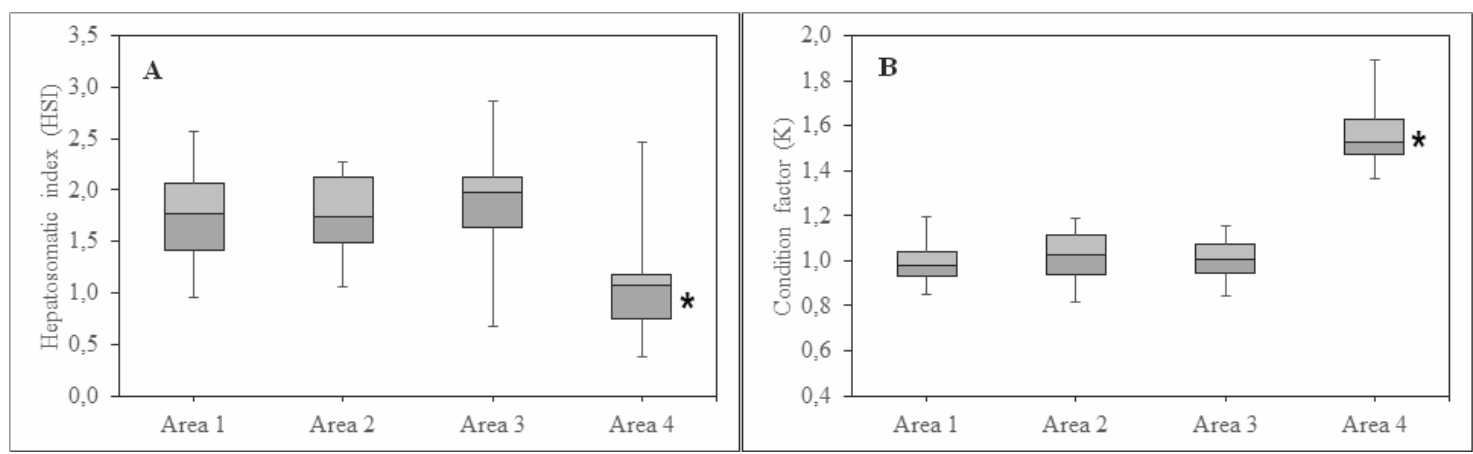

Figure 2. Boxplots showing hepatosomatic index (HSI) variation (A) and condition factor $(K)$ $(B)$ in the different sampled areas

Fish livers from the sampled points did not show many noticeable macroscopic abnormalities. Abnormalities, such as fat nodes, were identified in fish from sites A2, A3 and A4 and were more prevalent (31\%) in area A2 fish. These livers were characterized by the presence of fatty nodes with regions of tissue coloring ranging from yellow, green, black and red. Only $6 \%, 12 \%$ and $9 \%$ of the fish presented similar macroscopic abnormalities in areas A1, A3 and A4, respectively.

At all points sampled, MMCs prevailed in livers compared to any other type of lesion identified, at more than $90 \%$. Changes such as hyperplasia and lipid cells were also widely observed (>80\%) in areas A1, A2 and A3, with a lower frequency in the A4 area $(<60 \%)$.

The average number of MMCs $/ \mathrm{mm}^{2}$ was higher in areas A2 $(72.00 \pm 113.36)$ and A3 (70 \pm 50.59$)$, showing similarities between both (Fig. 3). Areas A1 $(41 \pm 21.52)$ and A4 $(22 \pm 16.50)$ had the lowest average $\mathrm{MMCs} / \mathrm{mm}^{2}$. The greatest variation occurred in area A2. The number of MMCs was significantly lower in individuals' livers from areas A1 and A4 ( $<0.05)$ compared to individuals from areas A2 and A3. A statistical difference $(p=0.01)$ was observed in hepatic MMCs among groups of individuals from the four areas observed.

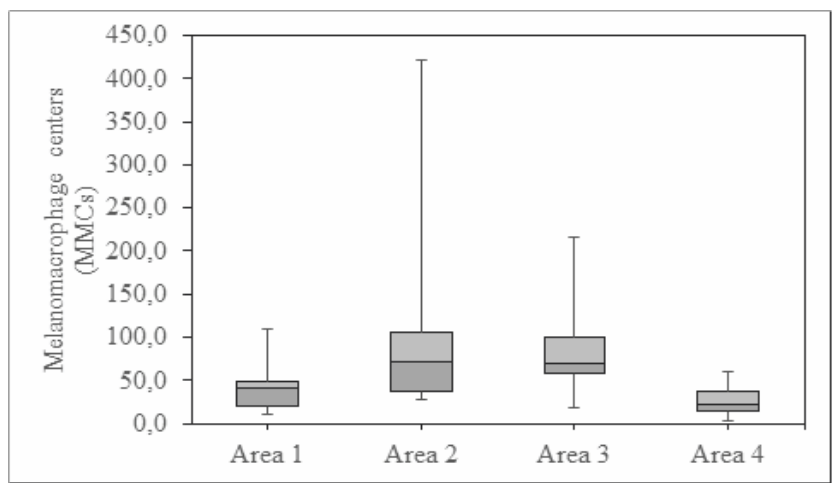

Figure 3. Boxplots showing melanomacrophage centers (MMCs) for S. herzbergii and B. bagre in the different areas sampled 
The most frequent hepatic lesions found in this study (>70\%) were lipid cells, hyperplasia, hypertrophy, necrosis, atrophy, intercellular edema and melanomacrophage centers. Hemorrhages, aneurysms, structural and nuclear alterations showed frequencies of intermediate lesions (40-70\%). While the other lesions, deposits, granuloma, neutrophilic infiltration and leukocyte infiltrate showed the lowest frequencies $(0$ 40\%) (Table 3).

Table 3. Histopathological alterations identified in the liver of S. herzbergii and B. bagre of each sampling point

\begin{tabular}{c|c|c|c|c|c|c}
\hline \multirow{2}{*}{ Reaction pattern } & \multirow{2}{*}{ Alteration } & \multirow{2}{*}{ w } & \multicolumn{4}{|c}{ Sampling sites } \\
\cline { 4 - 7 } & & & $\mathbf{A 1}$ & $\mathbf{A 2}$ & $\mathbf{A 3}$ & $\mathbf{A 4}$ \\
\hline \multirow{2}{*}{ Circulatory disturbances } & Haemorrhage/Hiperaemia/Aneurysm & 1 & 26.32 & 66.67 & 66.67 & 52.63 \\
& Intercellular edema & 1 & 73.68 & 60.00 & 86.67 & 68.42 \\
\hline \multirow{3}{*}{ Regressive changes } & Strctural alerations & 1 & 31.58 & 33.33 & 66.67 & 47.37 \\
& Lipidosis & 1 & 78.95 & 86.67 & 93.33 & 57.89 \\
& Deposits & 1 & 15.79 & 20.00 & 0.00 & 15.79 \\
& Nuclear alterations & 2 & 21.05 & 13.33 & 66.67 & 36.84 \\
& Atrophy & 2 & 36.84 & 60.00 & 80.00 & 57.89 \\
& Necrosis & 3 & 68.42 & 66.67 & 93.33 & 73.68 \\
\hline \multirow{3}{*}{ Progressive changes } & Hypertrophy & 1 & 63.16 & 73.33 & 86.67 & 52.63 \\
& Hyperplasia & 2 & 84.21 & 100.00 & 93.33 & 57.89 \\
& Granulomatosis & 2 & 36.84 & 13.33 & 26.67 & 15.79 \\
\hline \multirow{2}{*}{ Inflammation } & Leukocyte infiltrate & 2 & 10.53 & 13.33 & 20.00 & 26.32 \\
& Neutrophilic infiltration & 1 & 10.53 & 20.00 & 0.00 & 0.00 \\
& Melanomacrophages centres & 1 & 94.74 & 93.33 & 93.33 & 89.47 \\
\hline
\end{tabular}

Values givens as percentage (\%). The importance factor (w) of each alteration. Reference area for $S$. herzbergii (A1); impacted area (A2); contaminated area (A3). Reference area for B. bagre (A4)

A large number of circulatory disorders, such as hemorrhaging and edema (Fig. 4D) were identified in the four study areas; the A3 area demonstrated a greater amount of these lesions while the A2 area found the lowest incidence.

Regarding regressive changes, changes including cell necrosis (Fig. 4E), autolysis (Fig. 4C), and massive lipid cell presence (Fig. 4A) prevailed in the A3 area. Structural and nuclear changes also prevailed in the same region.

With regard to progressive changes, the presence of hyperplasia lesions (Fig. 4H) was more constant in the A2 region. A huge hypertrophy process in area A3 fish was also noted. The presence of granuloma $(F i g .4 F)$ prevailed in fish of area A1 and was less constant in fish of area A2.

Among inflammatory processes, hepatic melanomacrophagous centers (Fig. 4G) were the most frequent lesions compared to any other type of alteration identified. In all studied areas $(\mathrm{n}=115)$, hepatic MMCs $(60 \%)$ were characterized as multiple structures dispersed through the liver parenchyma. An increase in the number and size of these structures $(>100)$ was identified in $11 \%$ of assessed fish, while the presence of some of these structures $(<30)$ was observed in $21 \%$ of the investigated livers. Liver samples without MMCs were the case in only 5\% of the fish. A similar MMCs percentage distribution was noted for all the studied areas. However, at specific sites where a large increase in the number of MMCs was observed in a single liver sample, it was found in fish from areas $\mathrm{A} 2$ and $\mathrm{A} 3$. 
An inflammatory response characterized by mononuclear leucocyte infiltration (Fig. 4B) was identified in $26.32 \%$ of the fish in the A4 area. Similar responses were identified in the other study areas, 20\%, 13.33\%, 10.53\%, in areas A3, A2 and A1, respectively.

Tumors characterized as psammomatous bodies (Fig. 4C) were more common in area A2 and A3 fish. As there was no mitosis or necrosis, it was not possible to indicate benignity. No tumors were found in fish livers from areas A1 and A4.

In relation to the gills, the main histological changes consisted of secondary lamella deformity, partial fusion, total fusion, necrosis (regressive changes), hypertrophy and hyperplasia (progressive changes) (Table 4). It was also possible to observe parasite presence e in more than $1 / 4$ of the fish studied in area A2.

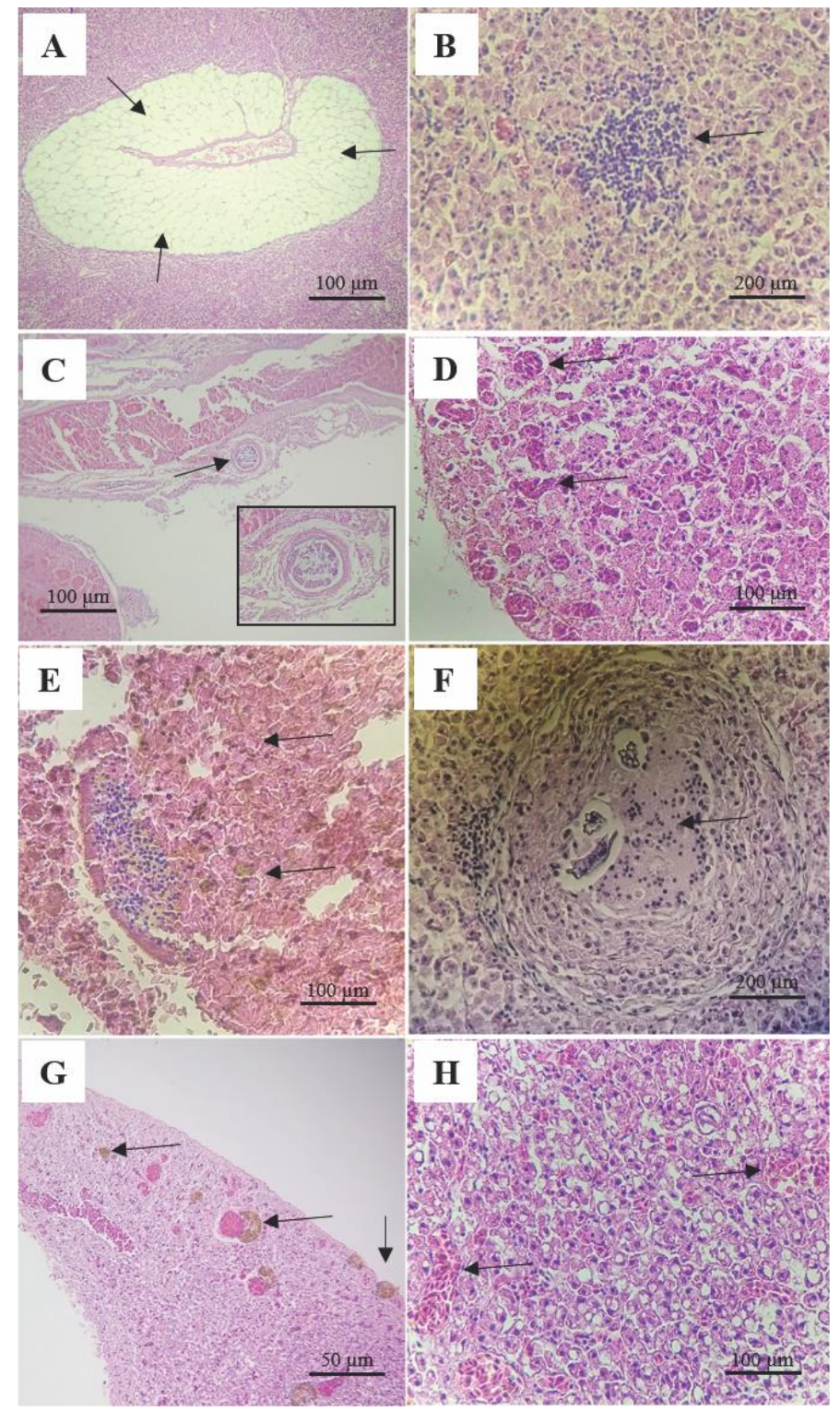

Figure 4. Photomicrography $(H \& E)$ of histopathological liver changes. (a) Macrovesicular steatosis (lipid cells). (b) Inflammatory response (leukocyte infiltrate). (c) Atrophy and tumor (psammomatous body). (d) Aneurysms and edema. (e) Necrosis. (f) Granulomatosis. (g) Melanomacrophage centers $(M M C s)$. (h) Hyperplasia. The arrow $(\rightarrow)$ indicates the changes found 
Table 4. Histological alterations identified in the gill of S. herzbergii and B. bagre of each sampling point

\begin{tabular}{c|c|c|c|c|c|c}
\hline \multirow{2}{*}{$\begin{array}{c}\text { Reaction } \\
\text { pattern }\end{array}$} & Alteration & \multirow{2}{*}{ w } & \multicolumn{4}{|c}{ Sampling sites } \\
\cline { 4 - 7 } & & & $\mathbf{A 1}$ & $\mathbf{A 2}$ & $\mathbf{A 3}$ & $\mathbf{A 4}$ \\
\hline \multirow{2}{*}{$\begin{array}{c}\text { Circulatory } \\
\text { disturbances }\end{array}$} & Haemorrhage/Hiperaemia/Aneurysm & 1 & 47.37 & 66.67 & 46.67 & 45.00 \\
& Profusion and dilation of blood vessels & 1 & 52.63 & 73.33 & 46.67 & 40.00 \\
& Intercellular edema & 1 & 42.11 & 26.67 & 33.33 & 20.00 \\
\hline \multirow{2}{*}{$\begin{array}{c}\text { Regressive } \\
\text { changes }\end{array}$} & Epithelial lifting & 1 & 26.32 & 80.00 & 40.00 & 25.00 \\
& Deformation of lamellae & 1 & 73.68 & 100.00 & 66.67 & 50.00 \\
& Partial lamellar fusion & 1 & 78.95 & 100.00 & 73.33 & 60.00 \\
Progressive & Necrosis & 3 & 5.26 & 100.00 & 53.33 & 40.00 \\
\hline changes & Total lamellar fusion & 1 & 63.16 & 80.00 & 66.67 & 55.00 \\
& Hypertrophy & 1 & 78.95 & 93.33 & 66.67 & 55.00 \\
& Hyperplasia & 2 & 73.68 & 100.00 & 66.67 & 55.00 \\
\hline
\end{tabular}

Values givens as percentage (\%). The importance factor (w) of each alteration. Reference area for $S$. herzbergii (A1); impacted area (A2); contaminated area (A3). Reference area for B. bagre (A4)

Despite the large number of gill lesions of the studied fish, the normal gill structure was also observed (Fig. 5A). The hyperplasia lesion was recorded in $100 \%$ of the specimens studied in area A2 (Fig. 5B), as well as necrosis, partial fusion (Fig. 5C) and lamella disorganization (Fig. 5D). Hypertrophy (Fig. 5E) also showed great representativeness in the four areas studied. In relation to circulatory disorders, the epithelial lining (Fig. 5F) was more prevalent, followed by venous sinus dilation and aneurysms (Fig. 5G). Parasite presence was observed in some cases (Fig. 5H).

For hepatic reaction patterns, Irp1 (circulatory disorders) reaction had the highest average in individuals in area A2 (126.50 \pm 40.44$)$, in March 2018 (rainy period). For this same reaction pattern, individuals from the A3 area showed values of $71.60 \pm 48.90$, in May, 2018 (rainy period). The lowest averages were found in the areas A4 $(15.00 \pm 0.00)$ and A1 $(2.00 \pm 0.71)$, respectively. In relation to Irp2 (regression changes) pattern $(104.50 \pm 104.52)$, Irp 3 (progressive changes) $(60.86 \pm 63.32)$ and Irp4 (inflammation) $(95.17 \pm 149.58)$, the specimens from area A2 also showed higher values than with other study areas. Consequently, the liver index was significantly higher $(91.48 \pm 103.46)$ in A2 individuals than the other specimens of areas A1, A4 and A3. However, the lowest organ index was also measured in the same area (19.5 \pm 15.87$)$. These higher averages correspond to individuals captured in March 2018 (rainy period) and the lowest ones in December 2017 (dry period). The lowest average in the Irp2 reaction pattern $(9.13 \pm 7.32)$ was observed in individuals from area A1, in December 2017 (dry period). The lowest average values of the $\operatorname{Irp} 3(14.69 \pm 8.26)$ and Irp4 $(13.25 \pm 5.19)$ were analyzed in individuals from the A4 area, in March and May 2018 (rainy period), respectively (Table 5).

The reaction patterns of the most representative branchial lesions were circulatory disorders in the A1 area. Fish collected in this area showed a higher index of the gill in September 2017 (dry period). The main lesions found in area A2 were progressive changes (Irp3) followed by circulatory disorders (Irp1). Fish collected in December 2017 (dry period) showed a higher index of the organ compared to the other specimens 
of all the research. For fish of area A3, the progressive changes were more representative and the organ index was higher in the rainy period (May 2018) in this region. Individuals in the A4 area showed a higher index of lesions related to progressive changes and the organ index was higher in September 2017. The gill index was significantly higher in individuals from area A2 than the other specimens from areas A1 and A3 (Table 6).

Table 5. Liver index of S. herzbergii and B. bagre for each site and sampled period

\begin{tabular}{c|c|c|c|c|c|c}
\hline \multirow{2}{*}{ Sampling sites } & \multirow{2}{*}{ Month } & \multicolumn{4}{|c|}{ Reaction pattern of the alteration } & Organ index \\
\cline { 3 - 7 } & & Irp1 & Irp2 & Irp3 & Irp4 & I Liver \\
\hline \multirow{3}{*}{$\begin{array}{c}\text { Reference site } S . \\
\text { herzbergii (A1) }\end{array}$} & Dec/17 & $2.00 \pm 0.71$ & $9.13 \pm 7.32$ & $19.17 \pm 13.96$ & $56.60 \pm 13.43$ & $20.48 \pm 20.86$ \\
& Mar/18 & $16.80 \pm 8.66$ & $45.64 \pm 47.88$ & $26.29 \pm 21.71$ & $64.78 \pm 67.27$ & $38.48 \pm 45.25$ \\
& May/18 & $9.80 \pm 18.38$ & $20.89 \pm 18.38$ & $16.65 \pm 7.40$ & $102.2 \pm 54.41$ & $25.36 \pm 34.02$ \\
\hline \multirow{3}{*}{ Impacted site (A2) } & Dec/17 & $28.00 \pm 5.10$ & $9.43 \pm 4.95$ & $19.89 \pm 20.47$ & $33.33 \pm 2.62$ & $19.5 \pm 15.87$ \\
& Mar/18 & $126.50 \pm 40.44$ & $104.50 \pm 104.52$ & $60.86 \pm 63.32$ & $95.17 \pm 149.58$ & $91.48 \pm 103.46$ \\
& May/18 & $68 \pm 43.54$ & $59.9 \pm 58.25$ & $40.19 \pm 22.66$ & $142.4 \pm 108.19$ & $63.39 \pm 61.65$ \\
\hline \multirow{3}{*}{ Contaminated site } & Dec/17 & $2.00 \pm 1.00$ & $29.58 \pm 28.15$ & $19.43 \pm 16.98$ & $57.8 \pm 27.26$ & $27.88 \pm 27.03$ \\
& Mar/18 & $18.00 \pm 10.00$ & $20.53 \pm 19.54$ & $23.47 \pm 13.49$ & $32.6 \pm 16.57$ & $22.14 \pm 16.04$ \\
& May/18 & $71.60 \pm 48.90$ & $44.59 \pm 41.96$ & $30.12 \pm 19.90$ & $24.43 \pm 17.11$ & $42.29 \pm 38.62$ \\
\hline \multirow{2}{*}{ Reference site $B}$. & Dec/17 & $15.00 \pm 0.00$ & $58.50 \pm 36.47$ & $22.44 \pm 16.19$ & $38.17 \pm 17.60$ & $38.08 \pm 29.53$ \\
bagre (A4) & Mar/18 & $20.10 \pm 12.26$ & $55.71 \pm 59.84$ & $14.69 \pm 8.26$ & $18.8 \pm 15.73$ & $30.77 \pm 41.15$ \\
& May/18 & $26.12 \pm 5.73$ & $40.23 \pm 41.37$ & $22.58 \pm 10.10$ & $13.25 \pm 5.19$ & $27.05 \pm 26.12$ \\
\hline
\end{tabular}

Values given as mean $(\bar{x})$ and standard deviation $( \pm \mathrm{SD})$. Reaction pattern: Irp1: circulatory disturbances; Irp2: regressive changes; Irp3: progressive changes; Irp4: inflammation

Table 6. Gill index of S. herzbergii and B. bagre to each site and period of collection

\begin{tabular}{c|c|c|c|c|c}
\hline \multirow{2}{*}{ Sampling sites } & \multirow{2}{*}{ Month } & \multicolumn{2}{|c|}{ Reaction pattern of the alteration } & Organ index \\
\cline { 3 - 6 } & & rp1 & rp2 & rp3 & I Gill \\
\hline \multirow{4}{*}{ Reference site for } & Sep/17 & $149.14 \pm 297.57$ & $59.00 \pm 29.81$ & $73.10 \pm 86.92$ & $86.57 \pm 165.08$ \\
S. herzbergii (A1) & Mar/17 & $25.00 \pm 32.47$ & $12.71 \pm 17.33$ & $12.80 \pm 11.14$ & $14.24 \pm 18.10$ \\
& May/18 & $7.30 \pm 3.29$ & $13.00 \pm 6.18$ & $15.33 \pm 17.46$ & $12.40 \pm 12.23$ \\
\hline \multirow{3}{*}{ Impacted site (A2) } & Sep/17 & $9.75 \pm 13.53$ & $77.05 \pm 202.14$ & $34.64 \pm 35.91$ & $49.44 \pm 141.94$ \\
& Dec/17 & $277.83 \pm 556.69$ & $59.67 \pm 72.01$ & $632.66 \pm 1080.34$ & $299.15 \pm 723.11$ \\
& Mar/18 & $9.50 \pm 8.50$ & $16.86 \pm 11.04$ & $31.20 \pm 35.20$ & $20.93 \pm 24.05$ \\
& May/18 & $17.33 \pm 10.09$ & $11.42 \pm 8.09$ & $32.31 \pm 28.12$ & $19.34 \pm 19.66$ \\
\hline Contaminated site & Sep/17 & & & & \\
(A3) & Dec/17 & $28.67 \pm 21.72$ & $81.29 \pm 113.02$ & $16.64 \pm 11.93$ & $36.07 \pm 65.03$ \\
& Mar/18 & $68.00 \pm 76.52$ & $15.93 \pm 76.52$ & $17.14 \pm 11.28$ & $26.27 \pm 42.76$ \\
& May/18 & $33.67 \pm 67.24$ & $12.60 \pm 8.76$ & $183.62 \pm 477.66$ & $81.71 \pm 307.50$ \\
\hline \multirow{2}{*}{ Reference site for } & Sep/17 & $3.50 \pm 1.50$ & $9.00 \pm 10.58$ & $131.75 \pm 100.01$ & $73.73 \pm 96.08$ \\
B. bagre (A4) & Dec/17 & $7.86 \pm 4.64$ & $23.71 \pm 17.32$ & $45.57 \pm 36.00$ & $28.84 \pm 28.49$ \\
& Mar/18 & $8.67 \pm 5.79$ & $7.33 \pm 4.64$ & $9.91 \pm 4.68$ & $9.24 \pm 4.99$ \\
& May/18 & $33.82 \pm 90.53$ & $9.21 \pm 8.31$ & $32.13 \pm 31.86$ & $22.97 \pm 56.10$ \\
\hline
\end{tabular}

Values given as mean $(\square)$ and standard deviation $( \pm \mathrm{SD})$. reaction pattern: Irp1: circulatory disturbances; Irp2: regressive changes; Irp3: progressive changes; Irp4: inflammation 

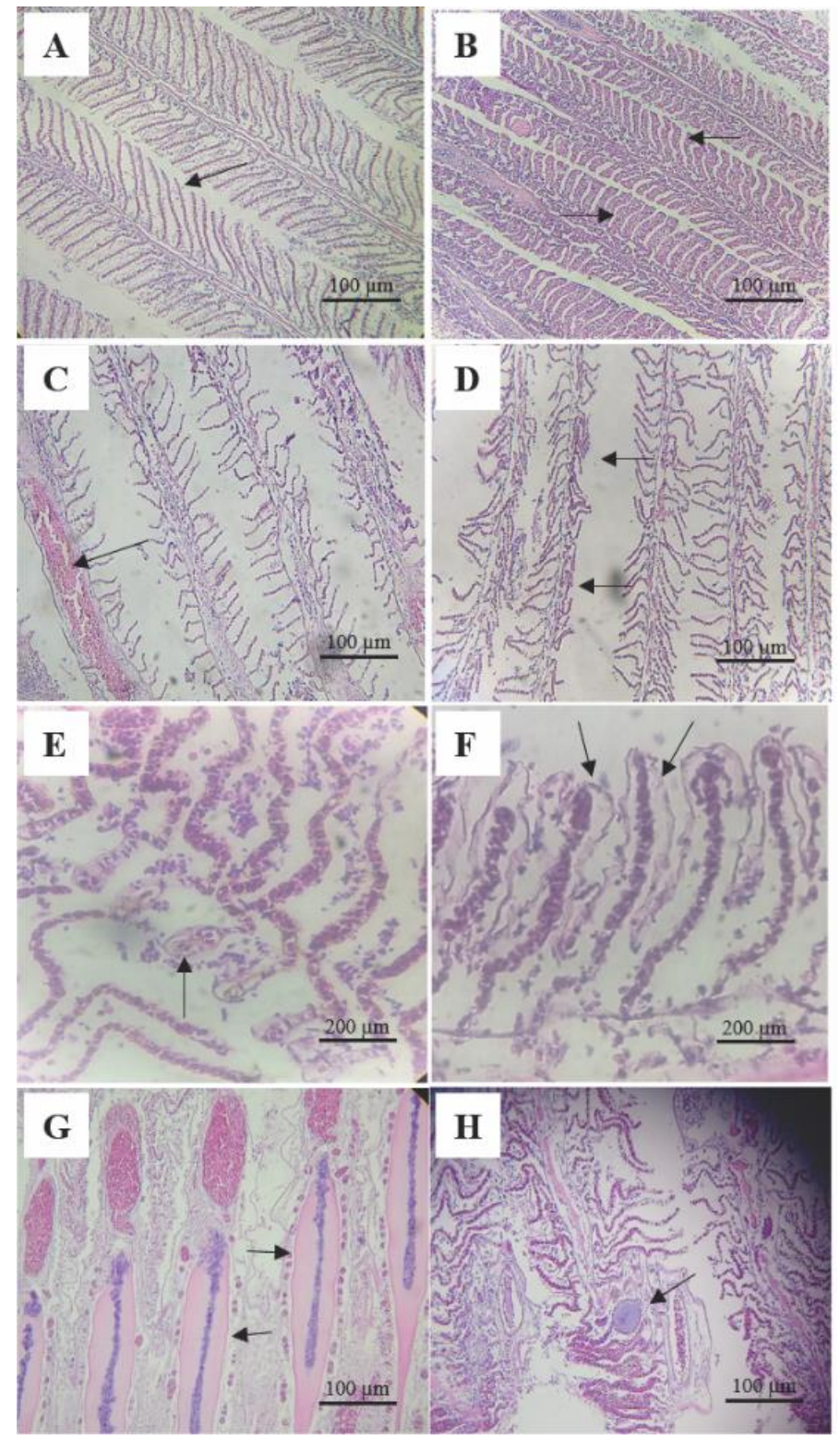

Figure 5. Photomicrography (H\&E) of histological gill changes. (a) Normal gills. (b) Hyperplasia. (c) Necrosis and partial fusion. (d) Secondary lamellae disorganization. (e) Hypertrophy. (f) Epithelium raising. ( $g$ ) Venous sinus dilation, total fusion and aneurysms. $(h)$ Parasites. The arrow $(\rightarrow)$ indicates the changes found

\section{Discussion}

In this study, the most frequent histological alterations in the liver were inflammatory responses (Melanomacrophage centers - MMCs), hyperplasia and cytoplasmatic vacuolization (lipid cells), which are common responses of fish exposed to degraded aquatic environments. The macroscopic appearance of nodules in tissue regions and the difference in staining between different organs examined show that the liver holds a large amount of fat and this was evidenced by microscopic and hepatocellular vacuolization results, characteristic of steatosis. The condition factor of the fish from areas A1, A2 and A3 obtained similar average values. Similar studies done recently with $S$. herzbergii collected in São Marcos Bay (Brazilian bay impacted by metals and 
PAHs close to the region of the present study) indicated many liver changes in fish, with emphasis on necrosis, leukocyte infiltration, fibrosis, melanomacrophage centers and steatosis (Pinheiro-Sousa et al., 2021).

A study carried out on the kidneys of Prochilodus lineatus showed positive correlation between condition factor, water temperature at different periods and the number of melanomacrotic centers (Balamurugan et al., 2012). Monitoring of fish hygiene conditions through fluctuation of the condition factor due to environmental changes has already been reported for feeding (Yan et al., 2015) and breeding cycles (Azevedo et al., 2017).

As with the condition factor, hepatosomatic index variation was similar between areas A1, A2 and A3 and differed from area A4. Comparing different area samples, the highest values of HSI were measured in areas A1, A2 and A3. The association between effluent release and fish liver size increase has been reported (Galloway et al., 2003; Saravanan et al., 2011). Phosphatic substances from sanitary effluents and fisheries can cause toxin production, such as microcystins, which can accumulate in fish liver (Deblois et al., 2011) and cause cellular changes. The high number of alterations such as hepatocyte hypertrophy may be related to the toxin presence as a result of the eutrophication process, which is potentiated by the release of high phosphororus levels in water bodies (Van Dyk et al., 2012). The presence of heavy metals in the water, in divergence with the amount permitted under Brazilian legislation (Resolução No 357, 2005), has already been reported in the investigated area, that is, in the lower course of the Santo Antônio river (Cantanhêde et al., 2016). A methodology through microbiological analyses and enzymatic responses in bivalves also indicated high levels of contamination in the same region and indicated a risk to human consumption (Ribeiro et al., 2016).

Abiotic factors such as temperature, $\mathrm{pH}$, conductivity and dissolved oxygen can change species richness and fish assemblage, which can also be attributed to anthropogenic impacts (Carvalho Neta et al., 2014). Similar studies in areas with the same characteristics as in this study have shown lower GSI averages in catfish from potentially contaminated areas and suggest that this decrease may result in abnormal gonad development, late maturation, high levels of atresia and fish intersexuality (Carvalho-Neta and Abreu-Silva, 2010; Carvalho Neta et al., 2014).

Similar to the biometric indices, results from microscopic analyses also showed differences between the period and the different sites. Liver index was significantly high in area A2 and high in area A3 compared to fish in areas A1 and A4. This pattern was identified by HSI results as well as microscopy and macroscopic analyses' results. Fish livers from area A2 and A3 were severely affected in terms of liver health, as evaluated in this study. Histopathological results showed a clear and specific difference between the sites accessed, reflecting the pollution level in these systems. Histological change variation associated with the reaction pattern was identified, however, high prevalence of regressive changes in fish suggests that most histological changes in fish from natural environments are regenerative (Van Dyk et al., 2012).

The liver plays a number of essential functions for organisms, which increases the concern with bioaccumulation and public health. Its functions include carbohydrate metabolism, lipid storage, synthesis and fatty acid oxidation and glycogen storage, as well as being the main detoxification center (Choi et al., 2018).

Inflammatory responses were constituted by macrophage infiltration of hepatic tissue, defense cells with an important role in the immune response to foreign agents, 
whose function is to remove, by phagocytosis, foreign particles derived from cellular degradation (Passantino et al., 2014; Basilone et al., 2018). MMCs may increase in number and size depending on environmental stress conditions and have been used as a biomarker (Agius and Roberts, 2003). A study with Micropterus salmoides showed a significant increase in the number of MMCs in fish from an impacted area when compared to an uninfluenced area (Blazer et al., 1987). In this study, hepatic melanomacrophages of $S$. herzbergii were observed primarily close to blood vessels and involved in storage, relocation and recycling of iron compounds from sterile or damaged venous red blood cells. The highest number of quantified $\mathrm{MMCs} / \mathrm{mm}^{2}$ was detected in area A2 organisms and corresponded to the youngest specimens in the study.

The number of lipid cells found in the liver of B. bagre was lower in relation to the other three areas evaluated and the values for this same alteration were growing according to the level of impact of the area, A1 < A $2<$ A 3 for $S$. herzbergii. The results are probably related to the anthropic pollution gradient observed at the collection sites (Cantanhêde et al., 2016), since the concentration of xenobiotics in the environment increases the incidence of lesions suffered by the liver (Ghisi et al., 2016).

Cellular vacuolization is harmful from the moment that cellular metabolism is altered as a result of chemical stress, and may interfere with normal cellular functioning. These substances can cause major damage, such as necrosis. In addition, the accumulation of lipids in the vesicles constitutes a mechanism of cellular response when in the presence of lipophilic chemical agents. In an attempt to immobilize these substances, it prevents their interaction with the other cellular components and, in this case, minimizes its toxic effect (Olivares-Rubio and Vega-López, 2016). These results indicate prolonged physiological disturbances leading to glycogen depletion and lipid accumulation. The association of lipid cells with MMCs has been observed in fish from regions contaminated with xenobiotic mixtures (Triebskorn et al., 2008). Vacuolization and hepatocyte swelling are the most common lesions for nitrogen compounds (dos Santos Silva et al., 2018).

Histological parameters are generally indicative of irreversible damage as they are involved in high-level biological organization changes. An important impact of effluent exposure at the histological level was observed in this study. The main histological gill changes were hyperplasia, hypertrophy, partial fusion, total fusion and aneurysms. These lesions gradually affect gill functions and are responses for acute and/or chronic exposure to a wide variety of contaminants (Pérez et al., 2018).

Hyperplasia was characterized by increased cell proliferation, which may lead to melting lamellae and, more rarely, filaments (Hinton et al., 1992). Lamellar fusions are results of excessive epithelial cell proliferation in filaments and a natural defense mechanism to protect lamellar epithelium from direct contact with toxic agents (Vigário and Sabóia-Morais, 2014). Epithelial elevation, lamellar hyperplasia and fusion are changes resulting from a variety of stressors, such as metals, ammonia, phenolic infections by microorganisms and even ectoparasites (Hinton et al., 1992).

Aneurysms are usual results of pillar cell collapse and impairs vascularization integrity with the high-volume blood release that pulls the lamellar epithelium out (McCarthy and Shugart, 1990). The high rate of apoptosis or necrosis found in fish (A2) may be related to potential DNA damage caused by direct exposure to contaminants present in river water (Sales et al., 2017). In teleosteal fish, a significant apoptosis increase has been used as an aquatic environment biomarker after exposure to different types of xenobiotics known to damage aquatic animals' liver and gills (Piechotta et al., 1999). 
Cellular hypertrophy usually indicates cellular activity increase in and is a very common morphological alteration related to gill damage, leading to epithelium thickening (Almeida and Ribeiro, 2016). Cells respond to stress by adaptive changes that limit or repair damage, preventing cell death (Mosser et al., 1997). Parasite presence, as verified in fish in this research, is also dangerous for these animals' respiratory quality (Raine et al., 2017). This may be related to immunodeficiency defense, acid-base problems and even osmoregulation problems (Akaishi et al., 2004).

High histopathological index for the gill tissue in individuals from area A2 can be attributed to animals' high exposure to xenobiotics that reach this place, suggesting that these substances undergo an accumulation process there. In addition to the fishery effluents, this site receives agrochemical waste and sewage effluents in natura from riverside communities. In addition, no filtration processes were found for residues resulting from these anthropic activities, so water quality is compromised. This is reflected in health conditions in animals from this area.

In the lower course of the Santo Antônio River there is intense fishing activity (a large number of boats that use fuel) followed by the extraction of shellfish (constantly revolving the mud), in addition to the occupational process along the riverbanks and unrestrained population growth, which seriously interferes with natural systems. There are also erosive processes and leaching, which carry toxic materials into the waterways. The effects of contaminants in the aquatic environment cause serious problems in gill tissues considering the important functionalities of this organ in respiratory processes and osmotic and ionic regulation, which could lead to individuals' deaths (Ghisi et al., 2016).

Despite histopathological assessment results, other factors such as pollution level, fish age and sample size should be considered. In this study, fish were collected during the dry and rainy periods. Histopathological differences were identified with seasonal variations. Age determination samples were not performed. However, a macroscopic gonadal analysis was performed and it was found that a large quantity of juvenile's fish from the area close to the fishery (A2) showed a high quantity of MMCs in comparison to adult individuals from the A3 area. However, age determination is strongly recommended as part of a histological protocol standard for assessing fish sanity levels.

Results of this study will be useful for monitoring and managing the health of fish populations. It will allow specific liver and branchial lesion identification at a site and infer regional similarities and/or patterns in terms of histological changes of the liver and gill. This study provides a better understanding of health effects related to fish pollution by comparing polluted and relatively natural systems and advances our understanding of the normal range of liver and gill histology for $S$. herzbergii and $B$. bagre.

Santo Antônio River Basin administrators when making decisions about this body of water should consider these results. Biomonitoring studies are fundamental for the development of public policies that prioritize conservation. There is also a need for more effective inspections of xenobiotic components entering the site and decreasing their environmental quality, which compromises directly and indirectly dependent organisms' quality of life.

\section{Conclusion}

This study concluded that between the analyzed catfish species, the taxon Sciades herzbergii is the most suitable for monitoring environmental impacts in transitional 
areas and estuarine environments through histopathological gill assessment. This was confirmed by acute effects suffered by gills and the high number of lesions demonstrated on individuals inhabiting the potentially impacted area in comparison to the other areas studied.

High HSI, the low condition factor of fish in areas A2 and A3, and the high number of lesions caused in the liver of $S$. herzbergii and their chronic effects prove that the species is a good biomonitor for monitoring environmental impacts in areas of transition and estuarine environments.

In conclusion, that the species $S$. herzbergii and $B$. bagre was found to be adequate for environmental studies as it presented responses which could be identified, classified and quantified. However, further studies are needed to evaluate the extent of contamination in sediment and other structures the fishes. This study suggests a contamination of water resource due to the anthropogenic sources and a competent surveillance and monitoring program becomes extremely necessary to any attempt of managing the coastal areas in urbanized regions.

Acknowledgements. We thank the Laboratory of Biomarkers in Aquatic Organisms (LABOAq/UEMA) for their logistic support in the field and laboratory analyses. We thank the staff of the Maranhão State Research Foundation-FAPEMA for financial support.

\section{REFERENCES}

[1] Agius, C., Roberts, R. J. (2003): Melano-macrophage centres and their role in fish pathology. - Journal of Fish Diseases 26(9): 499-509.

[2] Akaishi, F. M., Silva De Assis, H. C., Jakobi, S. C. G., Eiras-Stofella, D. R., St.-Jean, S. D., Courtenay, S. C., Lima, E. F., Wagener, A. L. R., Scofield, A. L., Oliveira Ribeiro, C. A. (2004): Morphological and neurotoxicological findings in tropical freshwater fish (Astyanax sp.) after waterborne and acute exposure to water soluble fraction (WSF) of crude oil. - Archives of Environmental Contamination and Toxicology 46(2): 244-53.

[3] Almeida, E. A., Ribeiro, C. A. O. (2016): Pollution and Fish Health in Tropical Ecosystems. - $\quad$ CRC Press, Boca Raton, FL. https://www.taylorfrancis.com/books/9781482212891.

[4] Au, D. W. T. (2004): The application of histo-cytopathological biomarkers in marine pollution monitoring: a review. - Marine Pollution Bulletin 8: 817-834.

[5] Azevedo, J. W. de J., de Castro, A. C. L., Silva, M. H. L. (2017): Length-weight relation, condition factor and gonadosomatic index of the whitemouth croaker, Micropogonias furnieri (Desmarest, 1823) (Actinopterygii: Sciaenidae), caught in Lençóis Bay, state of Maranhão, eastern Amazon, Brazil. - Brazilian Journal of Oceanography 65(1): 1-8.

[6] Balamurugan, S., Deivasigamani, B., Kumaran, S., Sakthivel, M., Rajsekar, T., Priyadharsini, P. (2012): Melanomacrophage centers aggregation in P. lineatus spleen as bio-indicator of environmental change. - Asian Pacific Journal of Tropical Disease 2(2): S635-S638.

[7] Basilone, G., Gargano, A., Corriero, A., Zupa, R., Santamaria, N., Mangano, S., Ferreri, R., Pulizzi, M., Mazzola, S., Bonanno, A., Passantino, L. (2018): Liver melanomacrophage centres and CYP1A expression as response biomarkers to environmental pollution in European anchovy (Engraulis encrasicolus) from the western Mediterranean Sea. - Marine Pollution Bulletin 131: 197-204.

[8] Bernet, D., Schmidt, H., Meier, W., Burkhardt-Holm, P., Wahli, T. (1999): Histopathology in fish: proposal for a protocol to assess aquatic pollution. - Journal of Fish Diseases 22(1): 25-34. 
[9] Blazer, V. S., Wolke, R. E., Brown, J., Powell, C. A. (1987): Piscine macrophage aggregate parameters as health monitors: effect of age, sex, relative weight, season and site quality in largemouth bass (Micropterus salmoides). - Aquatic Toxicology 10(4): 199-215.

[10] Brown-Peterson, N. J., Wyanski, D. M., Saborido-Rey, F., Macewicz, B. J., LowerreBarbieri, S. K. (2011): A standardized terminology for describing reproductive development in fishes. - Marine and Coastal Fisheries 3: 52-70.

[11] Cantanhêde, S. M., Medeiros, A. M., Ferreira, F. S., Ferreira, J. R. C., Alves, L. M. C., Cutrim, M. V. J., Santos, D. M. S. (2014): Uso de biomarcador histopatológico em brânquias de Centropomus undecimalis (Bloch, 1972) na avaliação da qualidade da água do Parque Ecológico Laguna da Jansen, São Luís-MA. - Arquivo Brasileiro de Medicina Veterinaria e Zootecnia 66(2): 593-601.

[12] Cantanhêde, S. M., da Silva Castro, G., Pereira, N. J., de Pinho Campos, J. S., da Silva, J., Tchaicka, L., Neta, R. N. F. C., de Souza Torres, J. R., Santos, D. M. S. (2016): Evaluation of environmental quality of two estuaries in Ilha do Maranhão, Brazil, using histological and genotoxic biomarkers in Centropomus undecimalis (Pisces, Centropomidae). - Environmental Science and Pollution Research 23: 21058-21069.

[13] Carvalho-Neta, R. N. F., Abreu-Silva, A. L. (2010): Sciades herzbergii oxidative stress biomarkers: an in situ study of an estuarine ecosystem (São Marcos' Bay, Maranhão, Brazil). - Brazilian Journal of Oceanography 58: 11-17.

[14] Carvalho-Neta, R. N. F., Abreu-Silva, A. L. (2013): Glutathione S-Transferase as biomarker in Sciades herzbergii (Siluriformes: Ariidae) for environmental monitoring: the case study of São Marcos Bay, Maranhão, Brazil. - Latin American Journal of Aquatic Research 41(2): 217-225.

[15] Carvalho-Neta, R. N. F., Torres, A. R., Abreu-Silva, A. L. (2012): Biomarkers in catfish Sciades herzbergii (teleostei: ariidae) from polluted and non-polluted areas (São Marcos' Bay, Northeastern Brazil). - Applied Biochemistry and Biotechnology 166(5): 13141327.

[16] Carvalho Neta, R. N. F., Sousa, D. B. P., de Almeida, Z. da S., Santos, D. M. S. and Tchaicka, L. (2014): A histopathological and biometric comparison between catfish (Pisces, Ariidae) from a harbor and a protected area, Brazil. - Aquatic Biosystems 10(1): 1-7.

[17] Choi, E., Alsop, D., Wilson, J. Y. (2018): The effects of chronic acetaminophen exposure on the kidney, gill and liver in rainbow trout (Oncorhynchus mykiss). - Aquatic Toxicology 198: 20-29.

[18] Deblois, C. P., Giani, A., Bird, D. F. (2011): Experimental model of microcystin accumulation in the liver of Oreochromis niloticus exposed subchronically to a toxic bloom of Microcystis sp. - Aquatic Toxicology 103: 63-70.

[19] dos Santos Silva, M. J., da Costa, F. F. B., Leme, F. P., Takata, R., Costa, D. C., Mattioli, C. C., Luz, R. K., Miranda-Filho, K. C. (2018): Biological responses of Neotropical freshwater fish Lophiosilurus alexandri exposed to ammonia and nitrite. - Science of the Total Environment 616-617: 1566-1575.

[20] Facey, D. E., Blazer, V. S., Gasper, M. M., Turcotte, C. L. (2005): Using fish biomarkers to monitor improvements in environmental quality. - Journal of Aquatic Animal Health 17(3): 263: 266.

[21] FAO (2018): The State of World Fisheries and Aquaculture (2018). Meeting the Sustainable Development Goals. - FAO, Rome.

[22] Galloway, B. J., Munkittrick, K. R., Currie, S., Gray, M. A., Curry, R. A., Wood, C. S. (2003): Examination of the responses of slimy sculpin (Cottus cognatus) and white sucker (Catostomus commersoni) collected on the saint john river (Canada) downstream of pulp mill, paper mill, and sewage discharges. - Environmental Toxicology and Chemistry 22(12): 2898-2907. 
[23] Garcia-Santos, S., Monteiro, S. M., Carrola, J., Fontainhas-Fernandes, A. (2007): Alterações histológicas em brânquias de tilápia nilotica Oreochromis niloticus causadas pelo cádmio. - Arquivo Brasileiro de Medicina Veterinária e Zootecnia 59(2): 376-381.

[24] Ghisi, N. C., Oliveira, E. C., Mendonça Mota, T. F., Vanzetto, G. V., Roque, A. A., Godinho, J. P., Bettim, F. L., Silva de Assis, H. C. da Prioli, A. J. (2016): Integrated biomarker response in catfish Hypostomus ancistroides by multivariate analysis in the Pirapó River, southern Brazil. - Chemosphere 161: 69-79.

[25] Hammer, Ø., Harper, D. A. T., Ryan, P. D. (2001): Past: Paleontological Statistics software package for education and data analysis. - Palaeontologia Electronica. http://palaeo-electronica.org.

[26] Hinton, D. E., Baumann, P. C., Gardner, G. R., Hawkins, W. E., Hendricks, J. D., Murchelano, R. A., Okihiro, M. S. (1992): Histopathologic Biomarkers. - In: Huggett, R. J., Kimerle, R. A., Mehrle, P. M., Bergman, H. L. (eds.) Biomarkers; Biochemical, Physiological, and Histological Markers of Anthropogenic Stress. - Boca Raton, FL: Lewis Publishers: 155-209. http://pubs.er.usgs.gov/publication/70187932.

[27] Instituto Brasileiro de Geografia e Estatística (IBGE) (2016): Produção da Pecuária Municipal. - IBGE, Rio de Janeiro.

[28] McCarthy, J. F., Shugart, L. R. (1990): Biomarkers of Environmental Contamination. Lewis Publishers, Chelsea, MI. https://www.osti.gov/biblio/5313124.

[29] Mosser, D. D., Caron, A. W., Bourget, L., Denis-Larose, C., Massie, B. (1997): Role of the human heat shock protein hsp70 in protection against stress-induced apoptosis. Molecular and Cellular Biology 17(9): 5317-5327.

[30] Olivares-Rubio, H. F., Vega-López, A. (2016): Fatty acid metabolism in fish species as a biomarker for environmental monitoring. - Environmental Pollution 218: 297-312.

[31] Olurin, K. B., Mbaka, G. O. and Agbato, O. A. (2016): Histopathological effect of sublethal concentration of aluminum phosphide (phostoxin) on Clarias gariepinus juveniles. - Pesquisa Veterinaria Brasileira 36(7): 574-580.

[32] Passantino, L., Santamaria, N., Zupa, R., Pousis, C., Garofalo, R., Cianciotta, A., Jirillo, E., Acone, F., Corriero, A. (2014): Liver melanomacrophage centres as indicators of Atlantic bluefin tuna, Thunnus thynnus L. well-being. - Journal of Fish Diseases 37(3): 241-50.

[33] Pérez, M. R., Rossi, A. S., Bacchetta, C., Elorriaga, Y., Carriquiriborde, P., Cazenave, J. (2018): In situ evaluation of the toxicological impact of a wastewater effluent on the fish Prochilodus lineatus: biochemical and histological assessment. - Ecological Indicators 84: 345-353.

[34] Piechotta, G., Lacorn, M., Lang, T., Kammann, U., Simat, T., Jenke, H. S., Steinhart, H. (1999): Apoptosis in dab (Limanda limanda) as possible new biomarker for anthropogenic stress. - Ecotoxicology and Environmental Safety 42(1): 50-56.

[35] Pinheiro-Sousa, D. B., de Almeida, Z. da S., Carvalho-Neta, R. N. F. (2013): Integrated analysis of two biomarkers in Sciades herzbergii (Ariidae, Siluriformes), to assess the environmental impact at São Marcos' Bay, Maranhão, Brazil. - Latin American Journal of Aquatic Research 41(2): 305-312.

[36] Pinheiro-Sousa, D. B., da Costa Soares, S. H., Torres, H. S., de Jesus, W. B., de Oliveira, S. R. S., Bastos, W. R., de Oliveira Ribeiro, C. A., Carvalho-Neta. R. N. F. (2021): Sediment contaminant levels and multibiomarker approach to assess the health of catfish Sciades herzbergii in a harbor from the northern Brazilian Amazon. - Ecotoxicol Environ Safety 208: 111540. DOI: 10.1016/j.ecoenv.2020.111540.

[37] Raine, J. C., Pietrock, M., Willner, K., Chung, K., Turcotte, D., Parrott, J. L. (2017): Parasitological analysis and gill histopathology of pearl dace (Semotilus margarita) and brook stickleback (Culaea inconstans) collected from the Athabasca oil sands area (Canada). - Bulletin of Environmental Contamination and Toxicology 98: 733-739.

[38] Resolução No 357, de 17 de março de 2005. - Diário Oficial. 
[39] Ribeiro, E. B., Bastos, L. S., Galeno, L. S., Mendes, R. S., Garino, F., Carvalho-Neta, R. N. F., Costa, F. N. (2016): Integrated assessment of biomarker responses and microbiological analysis of oysters from São Luís Island, Brazil. - Marine Pollution Bulletin 113: 182-186.

[40] RN39 CONCEA (2018): Resolução Normativa No 39 do CONCEA, de 20 de junho de 2018. - Diário Oficial da União.

[41] Sales, C. F., Santos, K. P. E. dos, Rizzo, E., Ribeiro, R. I. M. de A., Santos, H. B. dos Thomé, R. G. (2017): Proliferation, survival and cell death in fish gills remodeling: from injury to recovery. - Fish and Shellfish Immunology 8: 10-18.

[42] Saravanan, M., Prabhu Kumar, K., Ramesh, M. (2011): Haematological and biochemical responses of freshwater teleost fish Cyprinus carpio (Actinopterygii: Cypriniformes) during acute and chronic sublethal exposure to lindane. - Pesticide Biochemistry and Physiology 100(3): 206-211.

[43] Sardi, A. E., Renaud, P. E., da Cunha Lana, P., Camus, L. (2016): Baseline levels of oxidative stress biomarkers in species from a subtropical estuarine system (Paranaguá Bay, southern Brazil). - Marine Pollution Bulletin 113: 496-508.

[44] Triebskorn, R., Telcean, I., Casper, H., Farkas, A., Sandu, C., Stan, G., Colârescu, O., Dori, T., Köhler, H. R. (2008): Monitoring pollution in River Mureş, Romania, Part II: metal accumulation and histopathology in fish. - Environmental Monitoring and Assessment 141: 177-188.

[45] Van der Oost, R., Beyer, J., Vermeulen, N. P. E. (2003): Fish bioaccumulation and biomarkers in environmental risk assessment: a review. - Environmental Toxicology and Pharmacology 13(2): 57-149.

[46] Van Dyk, J. C., Cochrane, M. J., Wagenaar, G. M. (2012): Liver histopathology of the sharptooth catfish Clarias gariepinus as a biomarker of aquatic pollution. - Chemosphere 87(4): 301-311.

[47] Vazzoler, A. E. A. de M. (1996): Biologia da reprodução de peixes teleósteos: teoria e prática. - Editora da Universidade Estadual de Maringá, Maringá.

[48] Vigario, A. F., Saboia-Morais, S. M. T. (20214): Effects of the 2,4-D herbicide on gills epithelia and liver of the fish Poecilia vivipara. - Pesq. Vet. Bras. 34(6): 523-528.

[49] Vrana, B., Allan, I. J., Greenwood, R., Mills, G. A., Dominiak, E., Svensson, K., Knutsson, J., Morrison, G. (2005): Passive sampling techniques for monitoring pollutants in water. - TrAC - Trends in Analytical Chemistry 24(10): 845-868.

[50] Yan, G. J., He, X. K., Cao, Z. D., Fu, S. J. (2015): Effects of fasting and feeding on the fast-start swimming performance of southern catfish Silurus meridionalis. - Journal of Fish Biology 86(2): 605-614.

[51] Zhang, H., Pan, L., Tao, Y. (2014): Toxicity assessment of environmental pollutant phenanthrene in clam Venerupis philippinarum using oxidative stress biomarkers. Environmental Toxicology and Pharmacology 37(2): 697-704. 